\title{
PELATIHAN MANAJEMEN USAHA UNTUK MENIGKATKAN DAYA SAING KEPADA PARA PELAKU USAHA INDUSTRI KECIL DAN MENENGAH (UMKM) RANGINING DI DESA KADU GADUNG KECAMATAN CIPEUCANG KABUPATEN PANDEGLANG.
}

\author{
Suhandi ${ }^{1}$, Iqbal ${ }^{2}$, Siti Fatonah ${ }^{3}$, Siti Afifah ${ }^{4}$, Linda Juliani Hidayat ${ }^{5}$, Ira Fitriana Sari ${ }^{6}$ \\ 1,2,3,4,5,6 Universitas Bina Bangsa \\ Email : suhandi.binabangsa@gmail.com
}

\begin{abstract}
Abstrac
The majority of the residents of Kadu Gadung Village are farmers and rangining business actors, but their management is still simple and not managed systematically and well planned, so that they cannot provide maximum results. The purpose of this training is to increase competitiveness for industrial business actors small and medium scale rangining towards independent small industries. The implementation method is through: seminars for delivering material, discussions, practices, mentoring, monitoring and evaluation. The results of this training show that not all small and medium rangining industrial business actors in Kadu Gadung Village, which has not yet taken care of distribution permits, halal certificates, produces product innovations and online marketing, due to limited funds and human resources.
\end{abstract}

Keywords: training, business management, competitiveness, uikm

\begin{abstract}
Abstrak
Mayoritas penduduk warga Desa Kadu Gadung adalah petani dan pelaku usaha rangining, akan tetapi pengelolaannya masih sederhana dan tidak di kelola dengan sistematis dan terencana dengan baik, sehingga belum bisa memberikan hasil yang maksimal.Tujuan dari pelatihan ini untuk meningkatkan daya saing kepada para pelaku usaha industri kecil dan menengah rangining menuju industri kecil yang mandiri.Metode pelaksanaan melalui : seminar penyampaian materi, diskusi, praktek, pendampingan , monitoring dan evaluasi.Hasil dari pelatihan ini menunjukan bahwa belum semua para pelaku usaha industri kecil dan menengah rangining yang ada di Desa Kadu Gadung, yang belum mengurus surat ijin edar, sertifikat halal, memproduksi inovasi produk dan pemasaran online, karena keterbatasan dana dan sumber daya manusia.
\end{abstract}

Kata kunci: pelatiha, manajemen usaha, daya sain, uikm

\section{PENDAHULUAN}

Tingginya jumlah pencari kerja di Indonesia yang tidak sebanding lurus dengan ketersediaan jumlah lapangan pekerjaan, sehingga banyak masyarakat di seluruh Indonesia berusaha untuk menciptakan terobosan baru untuk meningkatkan daya saing demi memajukan perekonomian di daerah masing-masing.Tidak heran semakin banyak bermunculan pelaku usaha sektor industri usaha kecil dan menengah (UMKM). Sektor UMKM mempunyai peran yang sangat penting bagi pertumbuhan perekonomian di Indonesia.

Pengaruh kontribusi UMKM yang cukup besar terhadap perkembangan perekonomian nasional, ternyata sektor ini masih menyimpan beberapa permasalahan yang sangat mendasar. UMKM, masih lemah dalam penerapan manajemen usaha, kualitas sumber daya manusia yang masih terbatas, terkait modal usaha lemahnya akses ke lembaga keuangan, 
proses pemasaran yang berkelanjutan.Beberapa kendala yang dihadapi pengusaha kecil adalah keterbatasan di bidang permodalan, akses pasar, akses teknologi terapan, manajemen usaha serta masih kurangnya jiwa wirausaha dikalangan pelaku usaha kecil dan menengah. Sebagian besar para pelaku menjalankan usaha secara tradisional dan merupakan usaha turun temurun dari orang mereka, sehingga sulit untuk berkembang. Hal ini terjadi karena ketidaktauan akan pentingnya mengelola usaha atau usaha secara profesional.

Faktor penting yang menentukan keberhasilan dalam proses mengembangkan usaha adalah pada penerapan manajemen pengelolaan usaha. Banyak beberapa usaha yang tidak bisa berkembang karena pengelolaan usahanya yang kurang baik. Sehingga banyak modal usaha yang dimiliki lama para pelaku usaha lama- kelamaan akan habis juga jika tidak bisa mengelola dengan baik.Usaha seharusnya bisa terus tumbuh dan berkembang jika ditata dengan baik dan tersistem. Tetapi sebagian besar pemilik usaha hanya menjalankan usaha sekedarnya saja tanpa arah, tujuan, dan strategi yang terencana dengan baik.Kebanyakan pemilik usaha hanya menjalankan usaha saja, tidak membangun sistem yang mengarahkan langkah-langkah pelaksanaan yang pasti dalam usahanya, sehingga mereka harus bekerja seumur hidup agar usahanya tetap berjalan.

Sebagian besar pelaku usaha rangining di Desa Kadu Gadung Kecamatan Cipeucang Kabupaten Pandeglang adalah ibu rumah tangga. Warga Kadu Gadung terutama kaum ibu rumah tangga memproduksi rangining untuk membantu penghasilan perekonomian keluarga. Usaha rumaha ini mempunyai potensi besar untuk bisa terus dikembangkan. Karena permintaan pasar yang sudah ada saat ini cukup besar yaitu dari berbagai penjuru Kabupaten Pandeglang. Akan tetapi pengelolaan usaha rangining masih sangat sederhana dan tidak dikelola dengan baik, dan belum menerapkan manajemen usaha yang sistematis dan terencana dengan baik. Usaha industri kecil dan menengah rangining jika di kelola dengan penerapan manajemen usaha yang baik, maka akan berkembang menjadi industri rangining yang lebih besar dan maju sehingga dapat membuka lapangan pekerjaan, sehingga bisa mengurangi angka pengangguran di wilayah Desa Kadu Gadung itu sendiri, selain itu bisa menyerap tenaga kerja yang ada di luar Desa Kadu Gadung.Meningkatnya perekonomian bukan hanya untuk pelaku usaha industri kecil dan menengah rangining yang ada di Desa Kadu Gadung, akan tetapi juga berpengaruh terhadap meningkatknya perekonomian masyarakat Kecamatan Cipeucang Pandeglang dan sekitarnya. 

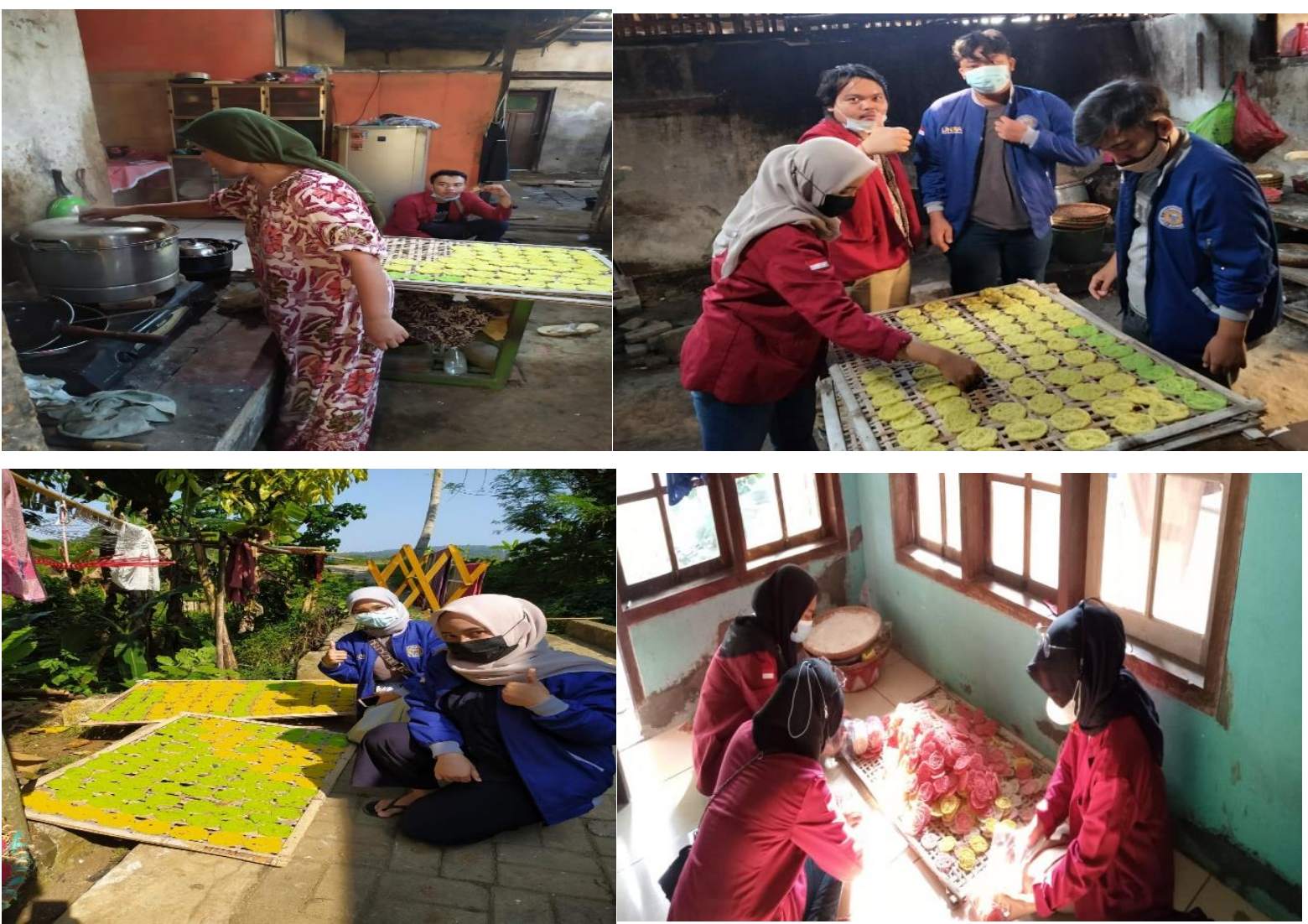

Gambar 1: menunjukan proses pembuatan” Rangining “masih sederhana

Dengan melihat permasalahan tersebut diatas kiranya perlu untuk memberikan pemberdayaan berupa pelatihan peningkatan manajemen usaha bagi para pelaku usaha industri kecil rumah tangga rangining di Desa Kadu Gadung. Desa Kadu Gadung terkenal dengan para pelaku usahanya. Sebagian besar masyarakat memiliki mata pencaharian sebagai pelaku usaha keripik rangining, buruh tani, petani sayuran, peternak kambing, budidaya ikan emas dan lele, kulang - kaleng , dan lain sebagainya. Desa Kadu Gadung identik dengan pengrajin rangining karena sebagian besar masyarakatnya dalam hal ini kaum ibu ibu. Para pedagang makanan ringan yang ada di sekitar Pandeglang dan sekitarnya membeli dari para pengelola atau pengrajin rangining yang ada di Desa Kadu Gadung Kecamatan Cipeucang Pandeglang.

Akan tetapi kemampuan dalam mengelola manajemen usaha yang dimiliki para pelaku usaha industri kecil dan menengah rangining, masih dapat digolongkan ke dalam kategori masih kurang baik. Sebagian besar para pelaku rangining masih menjalankan usaha sebagai pekerjaan sampingan belum dijadikan sebagai usaha tetap. Sebagian besar para pelaku usaha rangining belum memiliki surat ijin edar, kemasan keripik rangining yang 
digunakan belum memiliki inovasi yang menarik dan proses pemasaran hanya terbatas di sekitar Pandeglang saja, belum bisa keluar Kabupaten Pandeglang, sedangkan potensi yang dimiliki rangining yang di produksi para pelaku usaha di Desa Kadu Gadung sangat besar untuk dapat memasarkan rangining hingga ke kabupaten lain seperti Kabupaten Serang, Lebak dan Tangerang bahkan Jakarta.Dengan melihat latar belakang tersebut diatas kami berharap adanya perubahan ke arah yang lebih baik dari sebelumnya.

Tujuan diadakannya Pengabdian Kepada Masyarakat berupa pemberdayaan berupa pelatihan penerapan manajemen usaha antara lain : untuk meningkatkan keterampilan manajemn usaha sehingga mampu bersaing dengan pelaku usaha lain, menciptakan produk yang berkualitas sesuai dengan standar kesehatan, memahami pembuatan surat ijin edar, memahami pembuatan sertifikat halal, mampu menerapkan strategi pemasaran baik konvensional maupun pemasaran secara online, dengan demikian usaha para pelaku industri kecil dan menengah keripik talas beneng bisa berjalan dengan baik.Dengan demikian diharapkan dengan berkembangnya usaha para pelaku industri kecil rangining, usaha yang dijalankan bisa mengurnagi angka pengangguran serta meningkatkan perekonominan masyarakat Desa Kadu Gadung dan sekitarnya, meningkatkan kesadaran berwirausaha, dan meningkatkan kulaitas sumberdaya manusia.

Dalam rangka mencapai efektivitas yang tinggi dalam program pengabdian dan pemberdayaan masyarakat berupa pelatihan manajemen usaha ini, maka akan melibatkan beberapa pihak diantaranya: masyarakat sekitar Desa Kadu Gadung, pelaku usaha rangining, kelompok tani, aparat Desa Kadu Gadung, Tokok masyarakat, RW, RT, nara sumber dari Dinas Kesehatan Kabupaten Pandeglang, Dinas Koperasi dan UMKM Kabupaten Pandeglang, Dinas Perindustrian dan Perdagangan Kabupaten Pandeglang, Para Pelaku UMKM yang sudah sukses yang ada di tingkat kabupaten Pandeglang maupun provinsi Banten.

\section{METODE PELAKSANAAN}

Metode yang digunakan pada kegiatan pengabdian pemberdayaan masyarakat berupa pelatihan manajemen usaha kepada para pelaku usaha rangining yang ada di Desa Kadu Gadung, diantaranya dengan melakukan wawancara aparat RW dan RT Desa Kadu Gadung dan Aparat Desa Kadu Gadung untuk mengumpulkan informasi mengenai potensi desa dan kondisi masyarakat Desa Kadu Gadung sebagai kampung binaan. Selanjutnya wawancara juga dilakukan dengan beberapa pengelola atau pengrajin keripik talas beneng 
dan para petani talas beneng itu sendiri, untuk mengetahui respon mereka terhadap rancangan kegiatan pendampingan peningkatan kapasitas manajemen usaha kepada para pelaku usaha industri kecil dan menengah ( UIKM) Rangining. Hasil dari wawancara menunjukan respon yang positip baik dari aparat Desa Kadu Gadung maupun para pengelola usaha indistri kecil dan menengah rangining dan mereka bersedia untuk menjadi peserta mengikuti pelatihan manajemen usaha dalam rangka perkembangan usahanya.

Tim pengabdian dan pemberdayaan dalam hal ini kelompok 62 Kuliah Kerja Mahasiswa ( KKM ) Universitas Bina Bangsa, menentukan program yang menunjang pertumbuhan dan perkembangan usaha industri kecil dan menengah dalam hal ini pelaku usaha rangining yang ada di Desa Kadu Gadung Kecamatan Cipeucang Kabupaten Pandeglang.Dimana sebelumnya tim pengabdi mendapatkan data yang cukup melalui proses wawancara baik kepada apparat Desa Kadu Gadung maupun para pelaku usaha industri kecil dan menengah rangining yang ada di Desa Kadu Gadung.

Untuk memberikan pelatihan yang maksimal kepada para pelaku usaha keripik talas beneng, tim pengabdi pemberdayaan ( Tim KKM ) menghubungi narasumber - narasumber yang kompeten dalam bidang yang akan disampaikan kepada para pelaku usaha rangining diantaranya narasumber dari dari Dinas Kesehatan Kabupaten Pandeglang untuk memberikan pendidikan mengenai pengurusan ijin edar produk. Nara sumber lainnya adalah seorang motivator yang telah terlatih dalam memberikan pelatihan dan bimbingan untuk mengembangkan Usaha Industri Kecil dan Menengah. Tim pengabdi KKM UNIBA Kelompok 62, menentukan motivator dari Dinas Koperasi dan Usaha Mikro Kecil dan Menengah dan dari Dinas Perindustrian dan Perdagangan Kabupaten Pandeglang.Selanjutnya pengabdi menentukan narasumber adalah para pelaku Usaha Kecil dan Menengah yang sudah sukses baik tingkat Kabupaten maupun tingkat Provinsi.Kegiatan pelatihan di laksanakan di Posko KKM Kelompok 62 Desa Kadu Gadung, dengan jadwal yang telah ditentukan.Adapun metode pelatihan dan pendapingan dalam bentuk presentasi oleh nara sumber, diskusi, studi kasus, pembuatan rangining dengan menggunakan alat yang lebih praktis, sehingga bisa menghasilkan kualitas yang baik, dan penerapan strategi pemasaran dan pemasaran online. Setelah melakukan kegiatan pelatihan selanjutnya dilakukan monitoring dan evaluasi persiapan pelaku usaha untuk pengajuan persyaratan ke Dinas Kesehatan bagi pelaku usaha rangining yang belum memiliki ijin edar dan melakukan evaluasi atas pemahaman para pelaku usaha rangining sebelum dan sesudah diberikan pelatihan. Kegiatan selanjutnya yaitu dengan melakukan pendampingan pengajuan ijin surat edar jika ada diantara pelaku usaha rangining 
yang ingin mengajukan persyaratan dan monitoring dilakukan setelah kegiatan pelatihan untuk melihat lebih dalam tingkat pemahaman dan tindakan lanjutan yang diambil oleh para pelaku usaha rangining, setelah mendapatkan pelatihan.

\section{HASIL DAN PEMBAHASAN}

Kegiatan pelatihan dilakukan selama satu hari dan diisi oleh tiga narasumber. Hari pelatihan ditentukan setelah menyesuaikan antara waktu dari ketiga narasumber dan masa lapang mayoritas para pelaku usaha kecil dan menengah yang ada di Desa Kadu Gadung Pelatihan awali dengan regristrasi peserta pukul 08.00. Peserta pelatihan terdiri dari masyarakat Desa Kadu Gadung selaku pelaku usaha rangining dan di damping aparat desa. Pukul 09.30 dimulai pembukaan kegiatan dengan laporan kegiatan dari Ketua Tim KKM UNIBA 2021 Kelompok 62, selaku fasilitator. Kemudian dilanjutkan sambutan oleh Kepala Desa Kadu Gadung ( Almuktarodi ). Sambutan yang diberikan mengenai potensi dan peluang yang ada di Desa Kadu Gadung.Kepala Desa Kadu Gadung juga memberikan motivasi kepada warganya untuk lebih serius dalam mengembangkan usaha industri kecil dan menengah rangining yang sudah ada dan segera mengurus surat ijin edar agar produk yang dihasilkan dapat dipasarkan bukan saja di pasar terdekat melainkan dapat dipasarkan hingga ke kabupaten lain yang ada di Provinsi Banten.

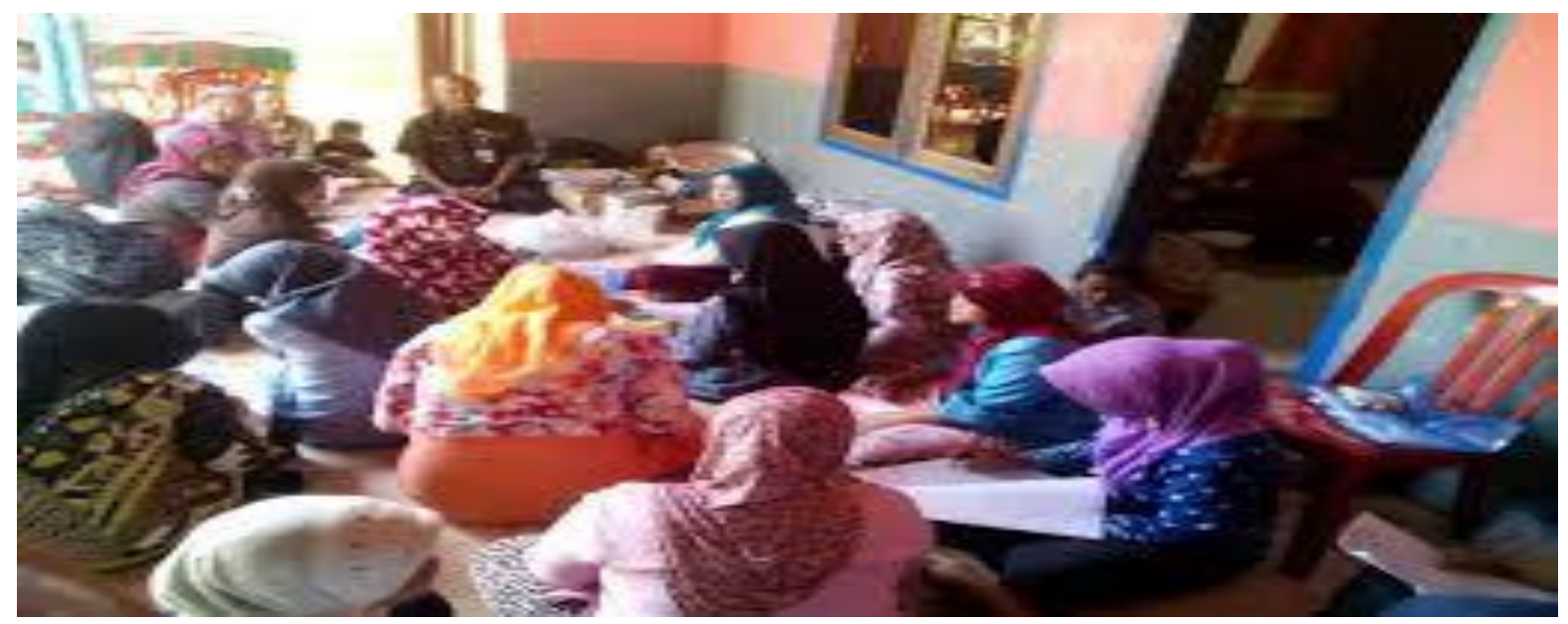

Gambar 2: suasana pelatihan manajemen usaha kepada para pelaku usaha "Rangining"

Bagian Pertama, pelatihan diberikan oleh Ustad.Tobari, selaku tokoh agama Desa Kadu Gadung sebagai narasumber dan pengabdi sebagai moderator. Beliau mengisi sesi pertama dengan memberikan pencerahan dan informasi mengenai hukum syara' berkaitan 
dengan produk halal dan kewajiban mengkonsumsi \& memproduksi makanan halal.Sebelum masuk ke materi utama, pengabdi merasa perlu memberikan pengantar dahulu dan untuk mengingatkan kembali para pelaku usaha rangining dan masyarakat bagaimana pentingnya bagi mereka untuk memperhatikan kehalalan dan kebaikan dalam memproduksi dan mengkonsumsi makanan. Pada sesi ini disampaikan materi mengenai hukum syara berkaitan dengan produk halal dan kewajiban mengkonsumsi dan memproduksi makanan yang berlebel halal.

Pada bagian Kedua materi disampaikan oleh perwakilan dari Dinas Kesehatan Kabupaten Pandeglang. Pada sesi ke pertama ini materi yang disampaikan mengenai tata cara pengajuan surat ijin edar. Diantara materi yang disampaikan adalah sebagai berikut mengapa perlu ada ijin edar, dan produk bersertifikat halal, Siapa saja yang mengurus ijin edar, permasalahan pangan seperti higiene sanitasi tempat pengelolaan makanan, pencemaran makanan, peralatan pengelolaan makanan, penjamah makanan, keracunan pangan, bangunan dan fasilitas yang dinilai seperti ruang produksi, kelengkapan ruang produksi, tempat penyimpanan, peralatan produksi, sumber air, fasilitas dan kegiatan, pengendalian hama, kebiasaan karyawan, pekerja seperti kebersihan pekerja, pekerja sakit tidak diperbolehkan masuk, kebersihan tangan pekerja, rambut dan mulut, label pangan, dan lain-lain..

Pada bagian kedua ini banyak pertanyaan dari para pelaku usaha rangining terkait : pengurusan ijin edar produk, bagaimna memproduksi sebuah produk sesuai dengan standar kesehatan, ngurus sertifikat halal, dan lain-lain.

Pada sesi ke Tiga materi di sampaikan dari Dinas Koperasi dan UMKM Kabupaten Pandeglang dan Dinas Perindustrian dan Perdagangan Kabupaten.Materi yang di sampaikan berupa bagaimana menjadi pelaku usaha yang sukses dan mandiri, bagaimna bisa menciptakan produk yang berkualitas sehingga bisa dinikmati dan bisa di beli oleh masyarakat luas.Selain itu materi yang di sampaikan dari Dinas Perindustrian dan Perdagangan berupa bagaimana cara memasarkan produk yang baik dan benar, dengan penerapan strategi pemasaran yang tepat sasaran dan juga pemasaran online.

Pada bagian ketiga ini banyak sekali pertanyaan dari para peserta pelatihan diantaranya terkait penerpan strategi pemasaran yang tepat sasaran, dan penerapan pemasaran online, dan juga bagaimana cara membuat sebuah produk yang berkualitas, bagaimana cara menjadi seorang pelaku usaha yang sukses dan maniri. 
Evaluasi atas capaian keberhasilan kegiatan ini dapat diketahui melalui beberapa indikator diantaranya:

1. Berdasarkan hasil evaluasi bahwa masih banyak para peserta pelatihan dalam hal ini para pelaku usaha rangining di Desa Kadu Gadung, masih banyak yang belum tahu terkait pengurusan ijin edar dan sertifikat halal, membuat produk sesuai standar kesehatan, menciptakan produk yang berkualitas yang bisa dinikmati dan dibeli oleh masyarakat luas, cara menerapkan strategi pemasaran yang tepat sasaran dan penerapan pemasaran online, dan bagaimana menjadi pelaku usaha kecil dan menengah yang sukses.

2. Untuk mengetahui daya serap dan pemahaman akan materi pelatihan yang di sampaikan, para peserta pelatihan di haruskan mengajukan beberapa pertanyaan yang terkait materi yang di sampaikan oleh para narasumber.Berdasarkan hasil diskusi para pelaku usaha rangining akhirnya banyak yang memahami bagaimana mengurus surat ijin edar, mengurus surat ijin halal, mereka mengetahui bagaimana memproduksi produk yang sesuai standar kesehatan, bagaimana menciptakan produk yang berkualitas, dan memasarkan produk dengan penerapan strategi pemasaran yang tepat dan menerpakan pemasaran online.

3. Kegiatan monitoring hari pertama pengabdi dan tim turun ke lapangan untuk melihat sejauh mana persiapan para pelaku usaha rangining, untuk mengajukan ijin edar, sertifikat halal, bagaimana memproduksi produk sesuai dengan standar kesehatan, bagaimana menerpkan strtaegi pemasaran.Sebagian besar mereka masih melakukan pembenahan dirumah produksi, cara produksi dan bahan yang digunakan serta tehnis lainnya belum dapat dibuat sesuai syarat yang telah dijelaskan ketika pelatihan dan sosialisasi oleh nara sumber dari Dinas Kesehatan Kabupaten Pandeglang maupun dari nara sumber lainya.

4. Kegiatan monitoring hari kedua sudah ada beberapa para pelaku usaha kecil dan menengah rangining yang mempersiapakn berkas terkait persyaratan pengurusan ijin edar, ada beberapa para pelaku usaha rangining yang sudah menerapkan standar kesehatan, juga ada beberapa para pelaku usaha rangining yang sudah menerapkan pemasaran secara online.

5. Kegiatan monitoring hari ke tiga : belum semua para pelaku usaha rangining menerapkan materi yang sudah di sampaikan oleh narasumber pada waktu pelatihan, 
belum di terapkan dalam menjalankan usahanya, karena keterbatasan modal dan sumber daya manusia.
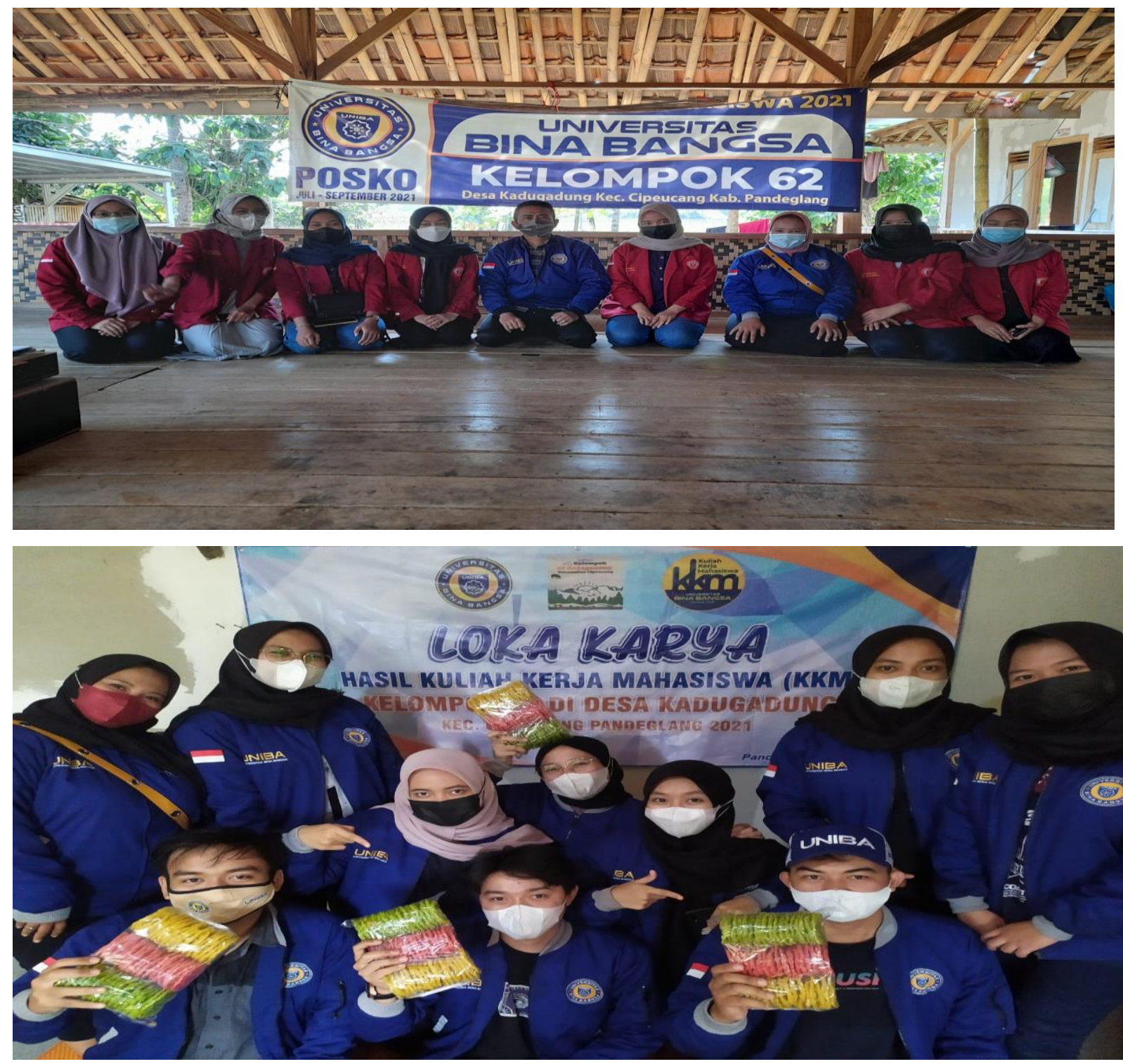

Gambar 3: Tim KKM UNIBA Kelompok 62.

\section{KESIMPULAN}

Kegiatan ini dilakukan di Desa Kadu gadung Kecamatan Cipeucang Kabupaten Pandeglang.Hasil dari pelatihan menunjukan bahwa mengurus ijin edar dan serifikat halal sangat di perlukan sebagai jaminan bahwa usaha makanan ringan yang merupakan usaha rumahan yang di jual memenuhi standar keamanan dan halal untuk di konsumsi.Para pelaku 
usaha rangining yang ada di Desa Kadu Gadung Kecamatan Cipeucang Pandeglang, masih banyak yang belum memilki pengetahuan dan pengalaman terkait ijin edar dan pembuatan sertifikat halal.Selain itu para pelaku usaha rangining yang ada di Desa Kadu Gadung, banyak yang belum memahami penerapan strategi pemasaran dan penerapan pemasaran onlie untuk meningkatkan penjualannya.

Ada beberapa keluhan yang dihadapi para pelaku usaha Rangining yang ada di Desa Kadu Gadung berdasarkan wawancara adalah para pelaku usaha keripik rangining ingin mendapatkan pendampingan mengenai surat iji edar, sertifikat halal, produk yang berkualitas, strategi pemasaran baik konvensional maupun pemasaran online.

Program kegiatan pengabdian kepada masyarakat Tim KKM UNIBA Kelompok 62 Desa Kadu Gadung, berupa pelatihan manajemen usaha kepada para pelaku rangining, ditambah kegiatan pendampingan, monitoring,dan evaluasi berlangsung selama satu hari penuh diikuti dua puluh lima ( 25 ) peserta para pelaku usaha rangining di Desa Kadu Gadung.Namun untuk proses pendampingan tidak dapat dilakukan karena ada beberapa pelaku usaha rangining yang belum siap untuk mengajukan permohonan pengurusan surat ijin edar dan sertifikasi halal. Salah satu faktor yang menghalangi adalah kondisi rumah produksi , pekerja dan produk belum sesuai dengan syarat minimal yang harus dipenuhi oleh pelaku usaha ketika ingin mengajukan ijin edar.

\section{Ucapan Terima Kasih:}

Tim KKM Uniba Kelompok 62 selaku pelaksana Pengabdian Kepada Masyarakat mengucapkan terimakasih kepada:

1. Tim LPPM Universitas Bina Bangsa

2. Kepada Desa Kadu Gadung Cipeucang Pandeglang

3. Para pelaku usaha rangining Desa Kadu Gaung.

\section{DAFTAR PUSTAKA}

1.Anggraeni, Feni Dwi. 2013. Pengembangan Usaha Mikro, Kecil dan Menengah (UMKM) Melalui Fasilitasi Pihak eksternal dan Potensi Internal (Studi Kasus pada Usaha Emping jagung di Kelurahan Pandanwangi Kecamatan Blimbing Kota Malang), Jurnal Administrasi Publik Vol 1, No 6 (2013) page. 1286-1295

2.Effendi, Syahril. 2005. Analisis Peningkatan Pengusaha Kecil Sesudah Mengikuti Pelatihan Kewirausahaan yang diseleggarakan oleh Swisscontact Medan. Jurnal Sistem Teknik Industri Volume 6. No 5. November 2005.

3.Hadi, Dwi Prasetyo. 2015. Strategi Pemberdayaan Masyarakat Pada Usaha Kecil 
dan Menengah Berbasis Sumber Daya Lokal Dalam Rangka Millenium Development Goals 2015 (Studi Kasus di PNPM-MP Kabupaten Kendal). Jurnal IImiah CIVIS, Volume V, No 1, Januari 2015

4.Undang-Undang No 20 Tahun 2008 Tentang Usaha Mikro, Kecil dan Menengah (UMKM).

5. Hadiyati, Ernani. 2009. Kajian Pendekatan Pemasaran Kewirausahaan dan Kinerja Penjualan Usaha Kecil. Jurnal Manajemen dan Kewirausahaan, Vol. 11 (2): 183-192.

6.Wilantara, R. F., \& Susilawati. (2016). Strategi Dan Kebijakan Pengembangan UMKM. Bandung: Refika Aditama.

7.Murhardjani. 2004. Pemberdayaan Pengrajin Tahu Tempe : Kajian Pengrajin Tahu Tempe di Kelurahan Mojosongo Kecamatan Jebres Kota Surakarta. Bogor: Sekolah Pascasarjana Institut Pertanian Bogor.

8.Haryono \& Koiriyah S. 2013.Pemberdayaan indusstri kecil dan menegah menuju kemandirian pembinaan kewirausahaan.FE Universitas Sebelas Maret

9.Kementrian Koperasi dan Usaha Kecil dan Menengah Republik Indonesia.2005.

Peran usaha mikro, kecil dan menengah dalam pembangunan ekonomi nasional.Surabaya.

10.Buku Pedoman Kuliah Kerja Mahasiswa (KKM-Tematik) PKM UNIBA 2021. 